\title{
Experimental Study on Lightning Discharge Attachment to the Modern Wind Turbine Blade with Lightning Protection System
}

\author{
Waqas Arif ${ }^{1}$, Qingmin $\mathrm{Li}^{1}$, Zixin Guo ${ }^{1}$, Manzoor Ellahi ${ }^{2}$, Guozheng Wang ${ }^{3}$, Wah Hoon $\mathrm{Siew}^{4}$ \\ ${ }^{1}$ School of Electrical and Electronics Engineering, North China Electric Power University, Beijing 102206, China \\ ${ }^{2}$ Department of Electrical Engineering, The Superior College (University Campus), Lahore 55150, Pakistan \\ ${ }^{3}$ School of Electrical Engineering, Shandong University, Jinan 250061, China \\ ${ }^{4}$ Department of Electronic and Electrical Engineering, The University of Strathclyde, Glasgow G1 1XQ, United Kingdom \\ waqasarif@qq.com, lqmeee@ncepu.edu.cn, guoxicin@126.com, manzoor.ellahi@superior.edu.pk, \\ guozhengwang@foxmail.com,wh.siew@strath.ac.uk
}

\begin{abstract}
Lightning strike is one of the most severe threats to the wind turbine blades and causes huge damage. Mostly wind turbines are struck by lightning when the blades are rotating. The effect of blade rotation on a lightning discharge attachment is unclear. Therefore, a rod electrode was used in a wind turbine lightning discharge test to investigate the difference in lightning triggering ability when blades are rotating and stationary. A standard switching waveform of $250 / 2500 \mu$ s was applied to the rod electrode. Lightning discharge tests of a 1:30 scale wind turbine model with $3 \mathrm{~m}$ air gaps were performed and the discharge process was observed. Three side receptors were used for Lightning protection system (LPS) of wind turbine blade (WTB). Distance between each receptor was $40 \mathrm{~cm}$ and $1^{\text {st }}$ receptor had $5 \mathrm{~cm}$ distance from tip of the WTB. Standard switching impulses (negative and positive) were applied to the WTB with different orientations and rotating speed. The experimental results demonstrated that when negative switching impulses were applied to the wind turbine blade, all the lightning discharges hit on the $1^{\text {st }}$ receptor; however, in the case of positive switching impulse, some discharges also hit on the other receptors, blade surface and nacelle of WTB. The attachment points remain same when the blade is stationary or rotating. The analysis revealed that polarity of switching impulse has significant influence on attachment point, and the rotation has little influence during the attachment process. The results can contribute to optimize the design of LPS of wind turbine blade.
\end{abstract}

Index Terms-Wind turbine blade, Lightning protection system, Receptor, Rotation, Lightning discharge, Attachment point

\section{INTRODUCTION}

$\mathrm{W}$ ind power generation is one of the most important renewable energy system. In China, more than 100,000 wind turbines (>169 GW) have been installed by the end of 2016 . Although wind turbines are equipped with lightning protection system designed to provide sufficient protection, the damage caused by lightning strikes remains one of the biggest threats to wind turbines. It costs huge losses to repair or replace the damaged blades, including maintenance cost and economic loss due to out of operation. And now there is a trend that more wind farms are built in mountainous area which will suffer severer lightning accidence. The size of wind turbines has increased dramatically and especially wind turbine blades have experienced a large development as shown in figure 1.

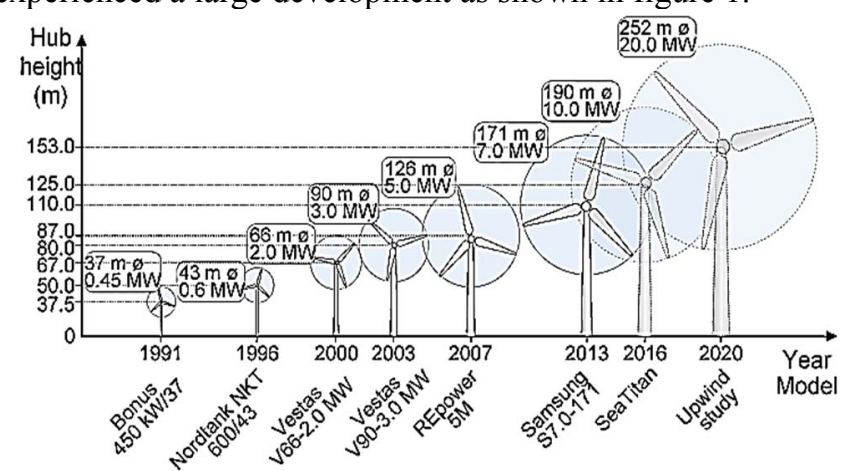

Fig. 1. Hub height, rated power and rotor diameter of several wind turbine models and their commission year $[1,2]$

Most manufacturers install discrete receptors along blade surface connecting to ground by down conductor, recommended by IEC standard 61400-24 [3]. As shown in Figure 2, two types of receptors are widely used, one is tip receptor installed at the tip of blade and the other one is side receptor installed at both sides of surface along the blade. Down conductor is installed adjacent to the web of beams along the wind turbine blade. The distance between receptors is about 5 to $10 \mathrm{~m}$. Field observation indicates that approximate $90 \%$ of lightning strikes hit on blade tip within 5 $\mathrm{m}$ and $10 \%$ hit on blade surface 5 to $10 \mathrm{~m}$ from the tip [4]. And it is interesting that lots of lightning strikes which cause damage just hit on the interval of two receptors [5-7].

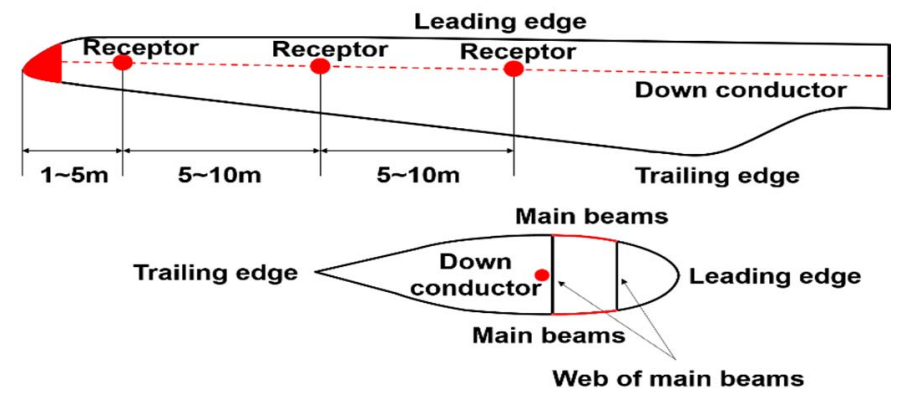

Fig. 2. Typical blade structure 
In wind farm lightning observation study, some researchers observed that wind turbine blades produce electrical discharges at regular intervals of $3 \mathrm{~s}$. This periodic effect has not been observed in static towers and indicates the strong effect of blade rotation [8]. Researchers observed that lightning strikes on a wind turbine and its neighboring lightning-protection tower that was equipped with various lightning observation instruments. They were compared with a stationary wind turbine and tower of a similar height, and the rotating wind turbine was more found to be likely to initiate an ascending leader. Thus, when a thunderstorm is overhead, it is advisable to stop wind turbine rotation [9].

The lightning protection system on the blades effectively directs a lightning current to the ground and thus reduces the risk of lightning damage to the blade. The main difference between receptors in modern wind turbine blade tips is their radius of curvature. The aim of the present study was to further determine the effect of blade orientation on lightning discharge attachment.

\section{EXPERIMENTAL WORK}

\section{A. Arrangement of the experimental setup}

Experiment tests were conducted outdoors at Shahe testing yard of North China Electric Power Research Institute (NCEPRI) in China, and more than 300 strikes were applied. Standard switching impulses (positive and negative) of 250/2500 $\mu$ s were obtained using a $5.4 \mathrm{MV}, 405 \mathrm{~kJ}, 28$ stages impulse generator. The discharge voltage was measured using a voltage divider. A rod electrode was employed as the downward leader and the vertical height between nacelle of wind turbine specimen and the bottom of rod electrode was 3 $\mathrm{m}$. A digital camera is used to capture the discharge behavior by long-exposure, and a high-speed camera Phantom V1210 is used to capture the attachment process. The frame rate is $240601 \mathrm{fps}(4.156 \mu \mathrm{s} /$ frame $)$, and the resolution is $128 \times 128$ pixel. The breakdown voltages were measured using an oscilloscope. The breakdown probability is approximately $100 \%$ for the applied voltage. The practical test platform configuration is displayed in figure 3(a).

\section{B. Description of scaled wind turbine model}

The model used in this study was a typical $3 \mathrm{MW}$ wind turbine model with 1:30 scaling ratio. The height of wind turbine from ground to nacelle was $4 \mathrm{~m}$. The scaled wind turbine model comprised of a blade, lightning protection system, support, and power transmission components. The scaled wind turbine model was placed directly underneath the high-voltage rod electrode. The scaled model of wind turbine is displayed in figure 3(b).

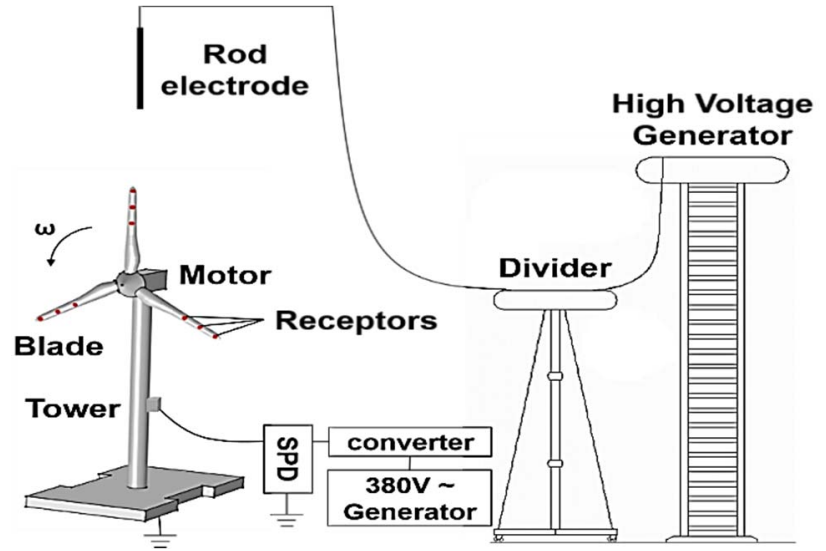

(a)

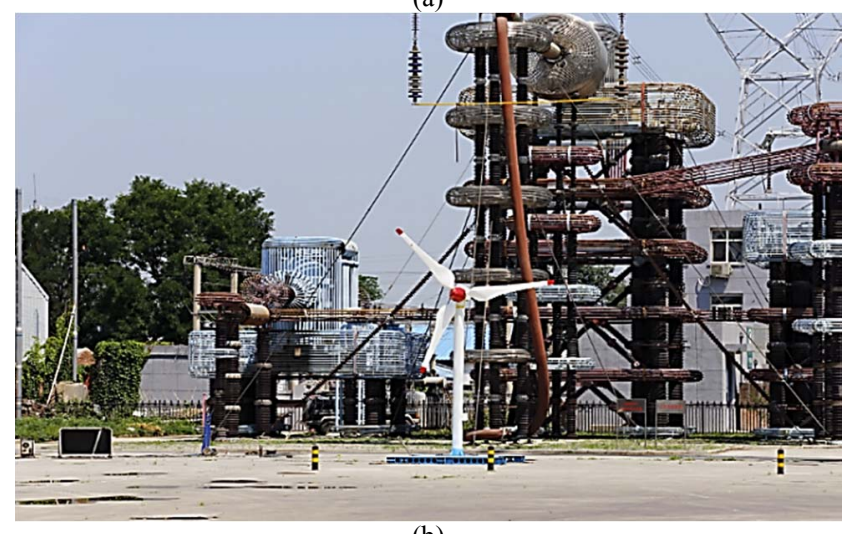

(b)

Fig. 3. Scaled model test arrangement (a) Test platform configuration, (b) Scaled model

The wind turbine scaled model had three blades of length 1.8 $\mathrm{m}$ that were constructed from Glass fiber reinforced polymer (GFRP). The typical blade structure is illustrated in figure 4. When a lightning strike occurred, the arc struck the receptor in the blade tip and current was transmitted to the ground mesh by the down conductor. There were three receptors $1^{\text {st }}, 2^{\text {nd }}$ and $3^{\text {rd }}$ on scaled wind turbine blade with circular copper disc 10.0 $\mathrm{mm}$ in diameter, placed at $5 \mathrm{~cm}, 45 \mathrm{~cm}$ and $85 \mathrm{~cm}$ from the tip of the blade respectively as shown in figure 4 .

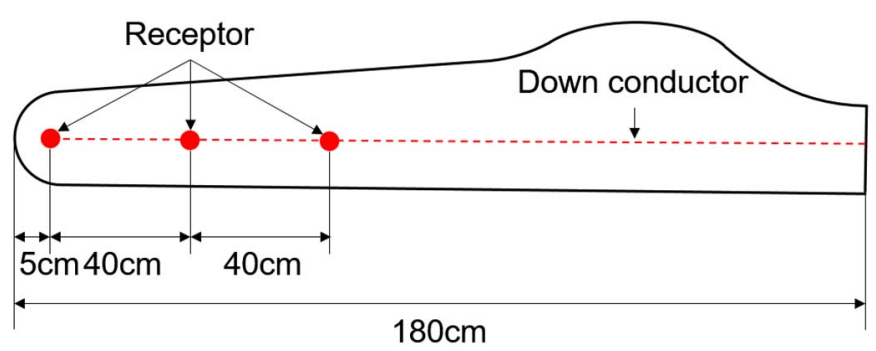

Fig. 4. Lightning protection system for modern wind turbine blade.

To ensure equivalence between the testing model and the actual situation, various factors that may affect the turbine's discharge characteristics were investigated, including air termination and blade rotation speed. Parameters such as 
discharge path, breakdown voltage, and time were used to characterize the discharge phenomena.

\section{RESULTS}

Experiments were conducted for different orientations of stationary wind turbine and rotating wind turbine with different revolutions per minute (rpm) under both positive and negative standard switching impulses. The results show very strong polarity effect. Further details of result are subdivided into following sections: In Section A, the effect of standard switching impulses (positive and negative) on stationary wind turbine blade. In Section B, the effect of standard switching impulses (positive and negative) on rotating wind turbine blade with $200 \mathrm{rpm}$ and $350 \mathrm{rpm}$.

\section{A. The effect of standard switching impulses (negative and positive) on stationary wind turbine blade}

Both positive and negative standard switching impulses were applied on stationary wind turbine blade with different orientations. The results are tabulated in Table I. When negative standard switching impulses were applied to the wind turbine blade with the orientation of $90^{\circ}, 60^{\circ}$ and $30^{\circ}$ with horizontal, all the lightning discharges struck to the $1^{\text {st }}$ receptor and not a single discharge struck to $2^{\text {nd }}, 3^{\text {rd }}$ receptors and blade surface. Figure 5 shows the successful attachments to the $1^{\text {st }}$ receptor under negative applied voltage.
In the case of positive applied voltage, results were dramatically changed, the positive standard switching impulses were applied to the wind turbine blade with $90^{\circ}$ and $60^{\circ}$ orientation all the lightning discharges struck to the $1^{\text {st }}$ receptor and not a single discharge struck to $2^{\text {nd }}, 3^{\text {rd }}$ and blade surface, but when 20 times positive switching impulses were applied to the wind turbine blade with $30^{\circ}$ orientation, then $50 \%$ lightning discharges hit on the $2^{\text {nd }}$ receptor and $50 \%$ lightning discharges hit on $3^{\text {rd }}$ receptor and no lightning discharge hit on the $1^{\text {st }}$ receptor and blade surface. When the results came different on $30^{\circ}$ orientation then positive voltage were applied to the $45^{\circ}$ orientation, so that it can be seen that at which orientation results become different. So that 20 times positive switching impulses were applied, then 55\% lightning discharges hit on the $1^{\text {st }}$ receptor and $45 \%$ lightning discharges hit on $2^{\text {nd }}$ receptor and no lightning discharge struck on the $3^{\text {rd }}$ receptor and blade surface. Discharge manners under positive standard switching impulses on stationary wind turbine blade with $90^{\circ}, 60^{\circ}, 45^{\circ}$ and $30^{\circ}$ orientation are shown in figure 6 . It can be seen from Table I that under negative applied voltage, the lightning discharges remains on $1^{\text {st }}$ receptor at any orientation, but under positive applied voltage the lightning discharge attachment point moves from $1^{\text {st }}$ to $2^{\text {nd }}$ and $3^{\text {rd }}$ receptor if orientation of WTB is less than $45^{\circ}$.

TABLE I. Experiment results of standard switching impulse on stationary wind turbine blade

\begin{tabular}{|c|c|c|c|c|c|c|c|}
\hline \multirow[b]{2}{*}{ Polarity } & \multirow{2}{*}{$\begin{array}{l}\text { Orientation } \\
\text { (with } \\
\text { horizontal) }\end{array}$} & \multirow{2}{*}{$\begin{array}{c}\text { Average breakdown } \\
\text { voltage } \\
(\mathrm{kV})\end{array}$} & \multicolumn{3}{|c|}{ Striking attachment point } & \multirow[b]{2}{*}{$\begin{array}{l}\text { Wind turbine blade } \\
\text { surface }\end{array}$} & \multirow[t]{2}{*}{ Totally } \\
\hline & & & $\begin{array}{l}1^{\text {st }} \\
\text { receptor }\end{array}$ & $\begin{array}{l}2^{\text {nd }} \\
\text { receptor }\end{array}$ & $\begin{array}{c}3^{\text {rd }} \\
\text { receptor }\end{array}$ & & \\
\hline Negative & $90^{\circ}$ & -1020.43 & 10 & - & - & - & 10 \\
\hline Negative & $60^{\circ}$ & -1284.92 & 10 & - & - & - & 10 \\
\hline Negative & $30^{\circ}$ & -1731.49 & 13 & - & - & - & 13 \\
\hline Positive & $90^{\circ}$ & 641.01 & 20 & - & - & - & 20 \\
\hline Positive & $60^{\circ}$ & 881.67 & 20 & - & - & - & 20 \\
\hline Positive & $45^{\circ}$ & 1073.13 & 11 & 9 & - & - & 20 \\
\hline Positive & $30^{\circ}$ & 1103.574 & - & 10 & 10 & - & 20 \\
\hline
\end{tabular}

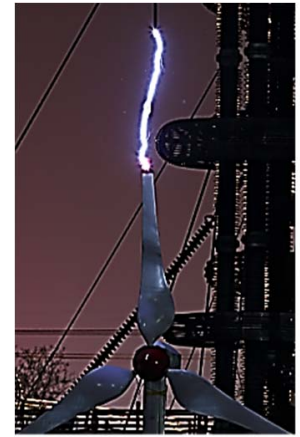

$90^{\circ}$

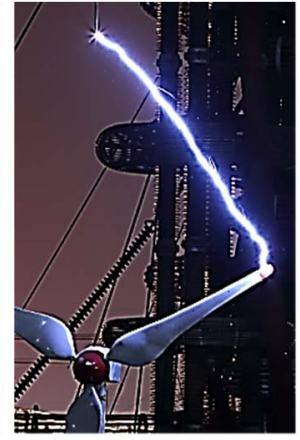

$60^{\circ}$

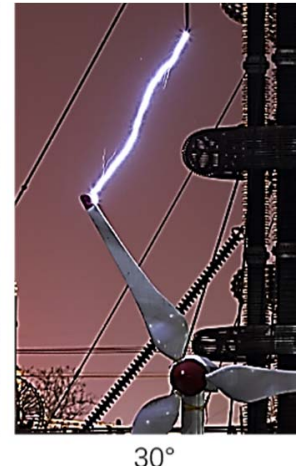

$30^{\circ}$
Fig. 5. Discharge manners under negative standard switching impulse on stationary wind turbine blade with the orientation of $90^{\circ}, 60^{\circ}$ and $30^{\circ}$ with horizontal
B. The effect of standard switching impulses (negative and positive) on rotating wind turbine blade

Both negative and positive standard switching impulses were applied on rotating wind turbine blade with different revolution per minute. The results are tabulated in Table II.

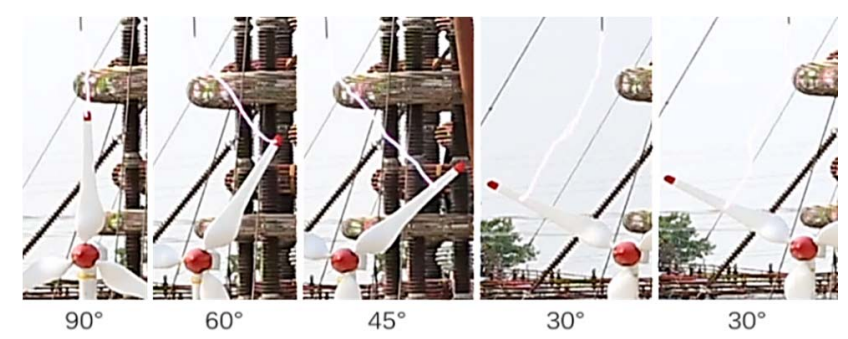

Fig. 6. Discharge manners under positive standard switching impulse on stationary wind turbine blade with the orientation of $90^{\circ}, 60^{\circ}, 45^{\circ}$ and $30^{\circ}$ with horizontal 
Negative voltages were applied to the wind turbine blade when its revolving speed was $200 \mathrm{rpm}$ and $350 \mathrm{rpm}$, then all the discharge struck on the $1^{\text {st }}$ receptor and not a single discharge hit on the $2^{\text {nd }}, 3^{\text {rd }}$ receptors and blade surface. The discharge manners of rotating wind turbine blade with revolving speed of $200 \mathrm{rpm}$ and $350 \mathrm{rpm}$ are shown in figure 7 and 8 respectively.

TABLE II. Experiment results of standard switching impulse on rotating wind turbine blade

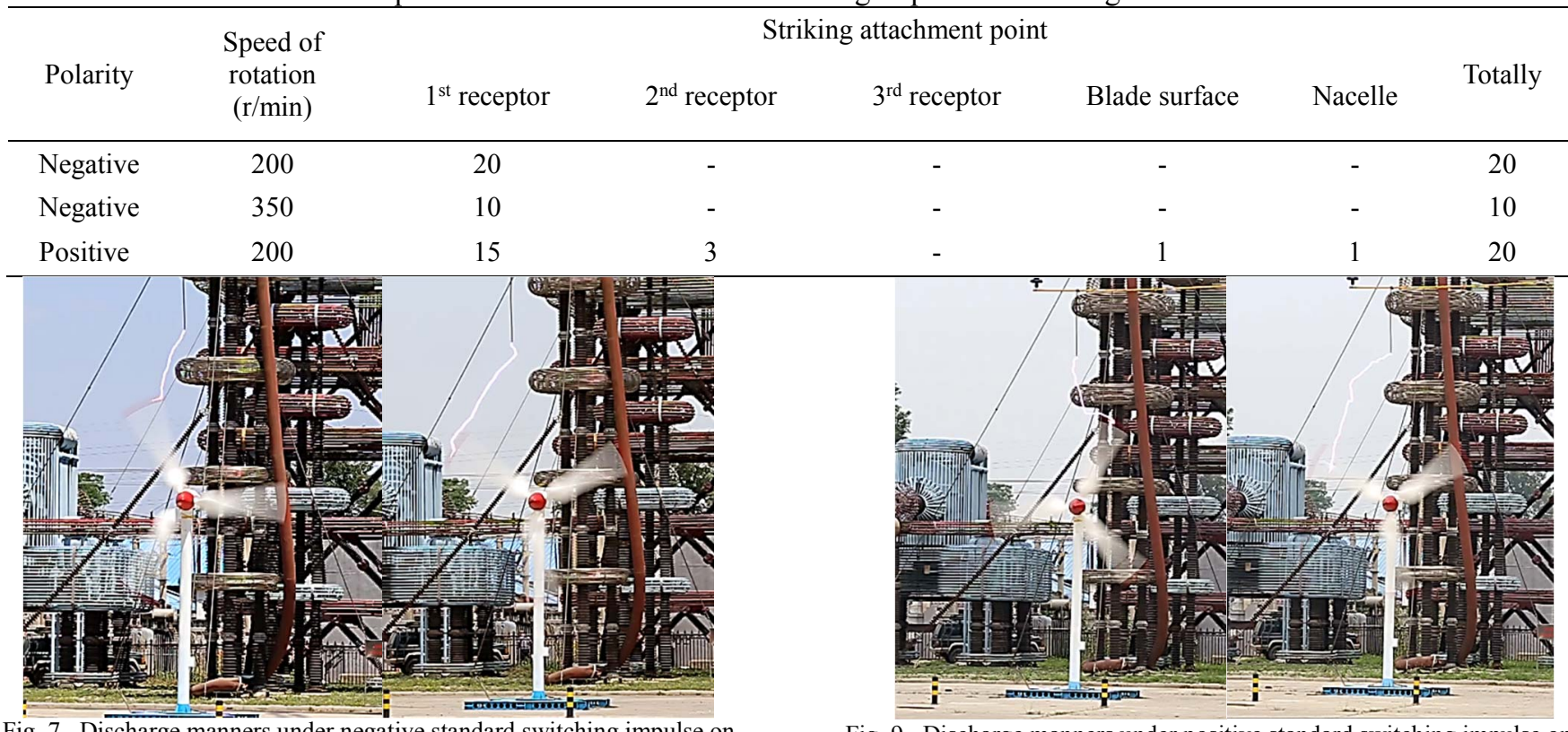

Fig. 7. Discharge manners under negative standard switching impulse on rotating wind turbine blade with $200 \mathrm{rpm}$

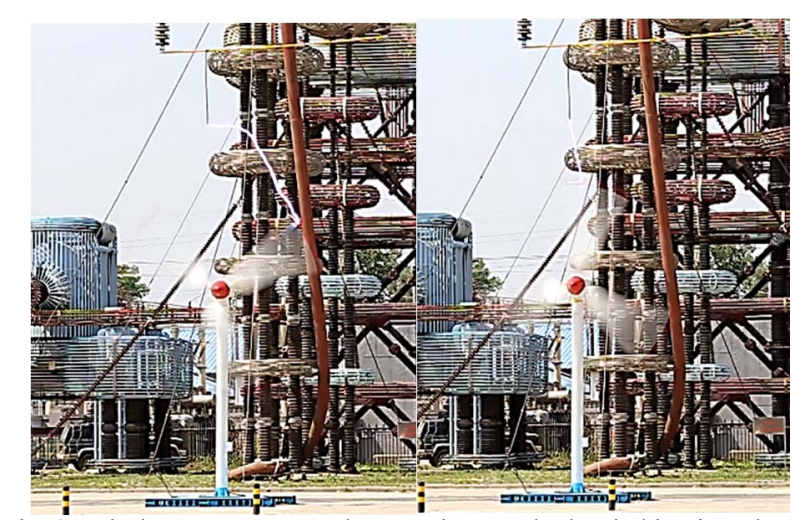

Fig. 8. Discharge manners under negative standard switching impulse on rotating wind turbine blade with $350 \mathrm{rpm}$

In the case of positive switching impulse some interesting lightning discharges were captured. 20 times positive switching impulses were applied and wind turbine was rotating with 200 rpm and lightning struck 15 times on $1^{\text {st }}$ receptor, 3 times on $2^{\text {nd }}$ receptor, 1 time on blade surface and 1 time on nacelle of wind turbine. Figure 9 shows the lightning discharge attachment under positive applied voltage on rotating wind turbine blade with $200 \mathrm{rpm}$.
Fig. 9. Discharge manners under positive standard switching impulse on rotating wind turbine blade with $200 \mathrm{rpm}$

Table II shows that $100 \%$ discharge struck to the $1^{\text {st }}$ receptor under negative switching impulses with different wind turbine rotation speed while under positive switching impulse some discharges struck on blade surface and nacelle of the wind turbine as shown in figure 10 and 11 respectively.

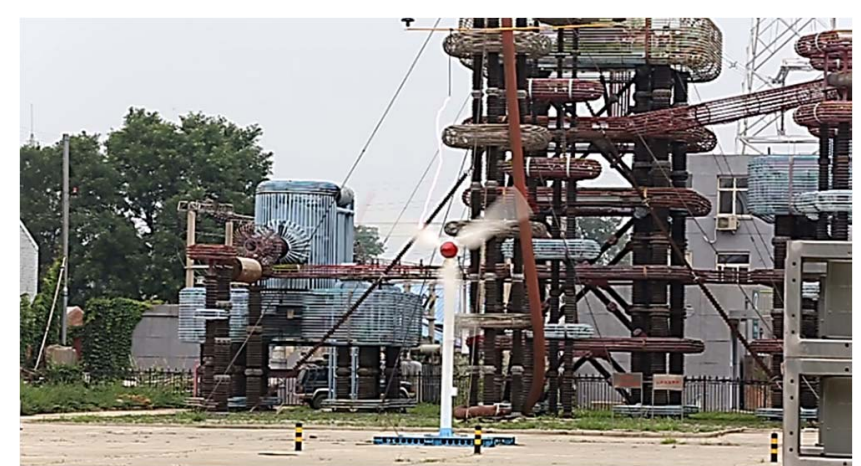

Fig. 10. Discharge struck on blade surface under positive standard switching impulse on rotating wind turbine blade with $200 \mathrm{rpm}$ 


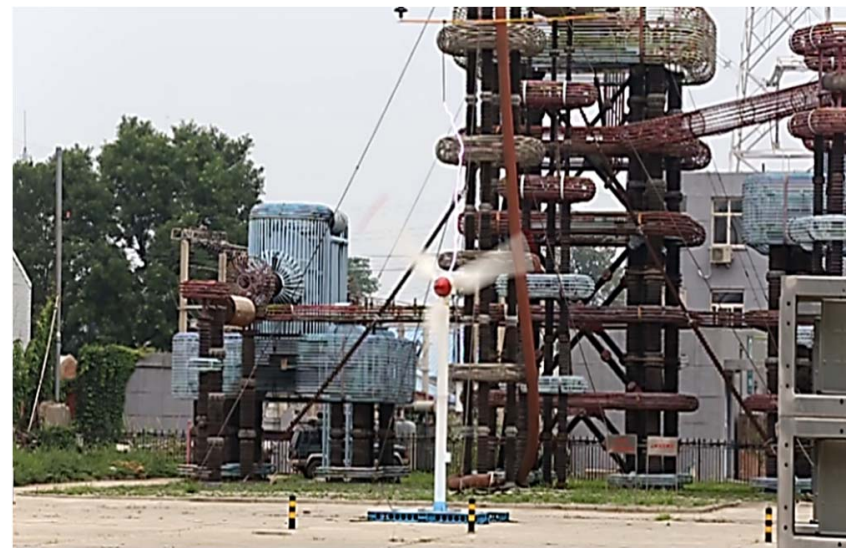

Fig. 11. Discharge struck on nacelle under positive standard switching impulse on rotating wind turbine blade with $200 \mathrm{rpm}$

\section{DISCUSSION}

Figure 12 shows the distribution of striking attachment points on the stationary wind turbine blade. It can be easily seen from the graph that when negative switching impulses were applied to the wind turbine blade with orientation from $90^{\circ}$ to $30^{\circ}$ all the discharges hit on the $1^{\text {st }}$ receptor but in the case of positive switch impulse orientations were decreased from $45^{\circ}$ to $30^{\circ}$, discharges struck on the $2^{\text {nd }}$ and $3^{\text {rd }}$ receptor.

\section{Distribution of striking attachment points on stationary wind turbine blade}

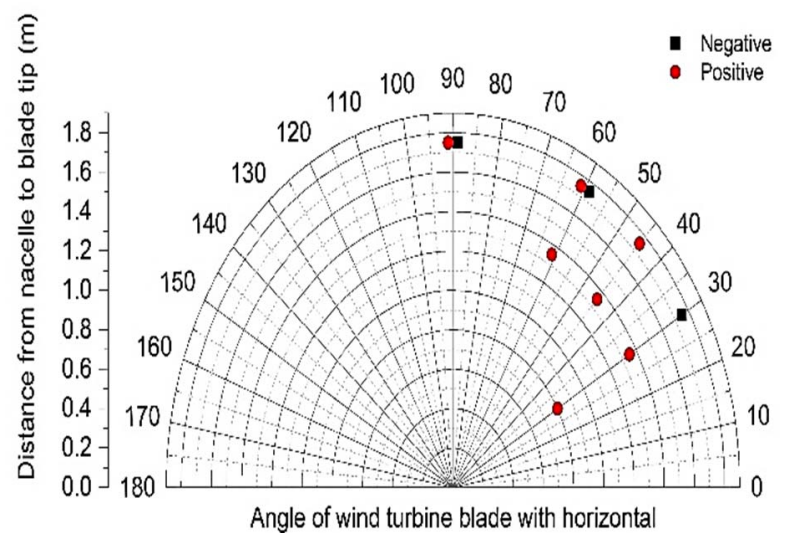

Fig. 12. Distribution of striking attachment points on stationary wind turbine blade under negative and positive impulse

Similarly, rotating WTB with revolving speed of $200 \mathrm{rpm}$ and $350 \mathrm{rpm}$, when negative switching impulses were applied, $100 \%$ discharges intercept with the $1^{\text {st }}$ receptor within the range of $90^{\circ}$ to $30^{\circ}$. Distribution of striking attachment points on rotating wind turbine blade with $200 \mathrm{rpm}$ and $350 \mathrm{rpm}$ under negative switching impulse is shown in Figure 13 and Figure 14 respectively.
Distribution of striking attachment points on wind turbine blade under negative impulse (200r/min)

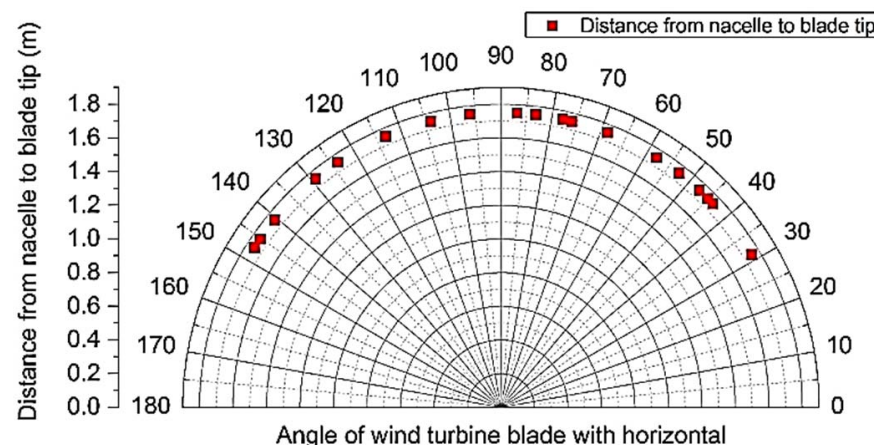

Fig. 13. Distribution of striking attachment points on wind turbine blade under negative impulse (200 r/min)

Distribution of striking attachment points on wind turbine blade under negative impulse $(350 \mathrm{r} / \mathrm{min})$

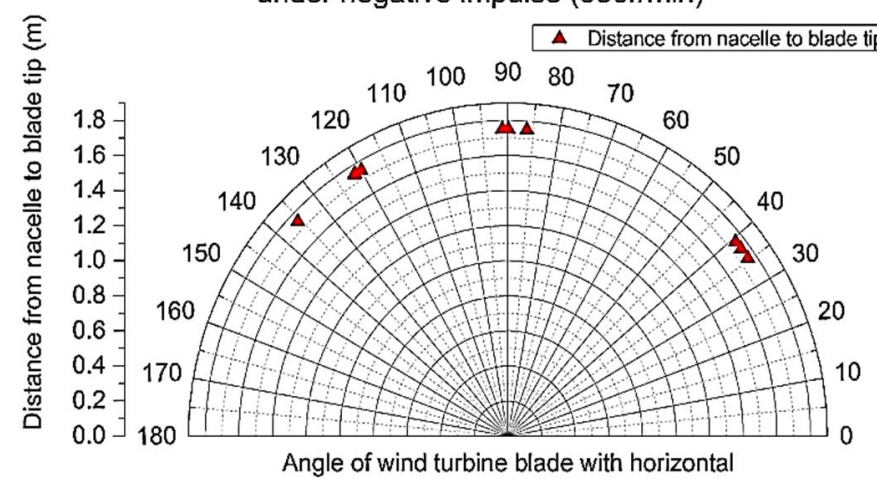

Fig. 14. Distribution of striking attachment points on wind turbine blade under negative impulse (350 r/min)

When positive switching impulse applied to the rotating wind turbine blade with revolving speed $200 \mathrm{rpm}$, then $75 \%$ discharges hit on the $1^{\text {st }}$ receptor and $15 \%$ discharges hit on the $2^{\text {nd }}$ receptor, two times LPS was failed to intercept the lighting discharge. Distribution of striking attachment points is shown in Figure 15. One time lightning discharge directly hit on the blade surface and one time on the nacelle of wind turbine shows the failure of LPS interception, so that still improvements are needed in LPS of wind turbine blade to intercept the $100 \%$ lightning discharge.

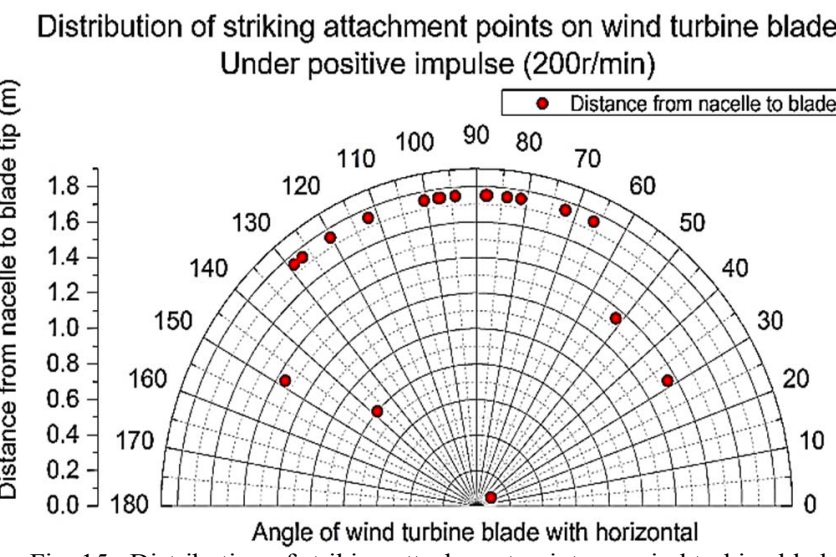

Fig. 15. Distribution of striking attachment points on wind turbine blade under positive impulse $(200 \mathrm{r} / \mathrm{min})$ 


\section{CONCLUSIONS AND RECOMMENDATIONS}

Experiments of lightning attachment are conducted to study the lightning attachment manner to wind turbine blades with lightning protection system under different blade orientation and rotation speed. The conclusion can be summarized as follows:

1. Negative polarity of standard switching impulse and rotation of WTB has no effect on lightning discharge attachment. Attachment points remain same when the blade is stationary or rotating and $100 \%$ discharge attached to the $1^{\text {st }}$ receptor.

2. Positive switching impulse has strong influence on lightning discharge attachment, in the case of stationary wind turbine blade if blade orientation is less than $45^{\circ}$, then lightning discharges attached to the $2^{\text {nd }}$ and $3^{\text {rd }}$ receptor and $1^{\text {st }}$ receptor fails to intercept the lightning discharge. However, in the case of rotating wind turbine blade, some time all the receptors fail to intercept the lightning discharge. The analysis revealed that rotation has little influence on lightning discharge attachment point.

3. The lightning protection system of wind turbine blade has better performance under the negative switching impulse than positive switching impulse.

4. Nacelle is a very important part of the wind turbine blade. During experiments, one time lightning discharge directly hit on the nacelle and LPS of wind turbine blade was failed to intercept the lightning discharge, so there should be a LPS on nacelle to protect it from lightning in case if LPS of WTB fails to intercept the lightning discharge.

5. The blade position significantly affects the attachment manner as well as the performance of the blade lightning protection system. Therefore, it is important to use lightning protection system suitable for all blade position.

\section{FUTURE WORK}

Experimental study of lightning protection systems and breakdown characteristic of new generation wind turbine blade under large air gaps and designing of LPS for nacelle of wind turbine to protect it from lightning.

\section{ACKNOWLEDGMENT}

This work was supported by National Natural Science Foundation of China (NNSFC) (51420105011) and the Fundamental Research Funds for the Central Universities (2016XS06). The authors would like to particularly thank to the staff of Shahe testing yard of North China Electric Power Research Institute (NCEPRI) for their consistent support throughout the experiment procedure.

\section{REFERENCES}

[1] Lindoe Offshore Renewables Center. List of Offshore Wind Farms. Available online: http://www.lorc.dk/offshore-windfarms-map/list (accessed on 1 March 2015).

[2] 4C Offshore. Offshore Wind Farms. Available online: http://www.4coffshore.com/windfarms (accessed on 23 March 2015).

[3] IEC 61000-24: 2010 Wind turbine generator systems - Part 24: Lightning protection, IEC, 2010.

[4] Garolera A C. "Lightning protection of flap system for wind turbine blades," PhD thesis, Tehcnical University of Denmark, 2014.

[5] Y. Ishige, N. Usui, et al, "New lightning protection for wind turbine blade," 2006 28rd International Conference on Lightning Protection (ICLP), Kanazawa, Japan, 2006, pp. 15711574.

[6] Sakamoto H, Kubo N, Hashimoto Y, et al, "Lightning Failure Protection of FRP Blades for Wind Power Generators," 2006 28 rd International Conference on Lightning Protection (ICLP), Kanazawa, Japan, 2006, pp. 1515-1521.

[7] Yokoyama S, Yasuda Y, Minowa M, et al, "Clarification of the mechanism of wind turbine blade damage taking lightning characteristics into consideration and relevant research project," Lightning Protection (ICLP), 2012 International Conference on. IEEE, 2012, pp. 1-6.

[8] Montanyà J, van der Velde $\mathrm{O}$ and Williams E R $2014 \mathrm{~J}$. Geophys. Res.: Atmos. 1191455.

[9] Wang D et al 2008 Geophys. Res. Lett. 351.

[10] Yu, W. A. N. G., et al. "Experimental study of rotating wind turbine breakdown characteristics in large scale air gaps." Plasma Science and Technology 19.6 (2017): 064016.

[11] F. Rachidi, M. Rubinstein, 1. Montanya, 1. L. Bermudez, R. R. Sola, Gloria Sola and N. Korovkin, "A review of current issues in lightning protection of new-generation wind turbine blades," IEEE Trans. Ind. Electron., Vol. 55,No. 6, pp. 2489-2496, June 2008. 